\title{
Economic Analysis of Production of Cut Roses under Polyhouses in Western Maharashtra
}

\author{
M.N. Waghmare* and P.N. Shendage \\ Associate Professor of Agricultural Economics, College of Agriculture, \\ Pune (Maharashtra), India
}

*Corresponding author

\begin{tabular}{|c|c|}
\hline & A B S T R A C T \\
\hline & \multirow{6}{*}{$\begin{array}{l}\text { Floriculture industry in India is in a boom in recent years. Maharashtra is the leading state } \\
\text { in India for cut roses consumption and export. The study is based on data collected from } \\
30 \text { producers growing cut roses in polyhouses around Pune city for the year } 2013-14 \text {. The } \\
\text { average cost of erection of polyhouse }(0.24 \text { ha.) was around Rs. } 23.13 \text { Lakhs. The average } \\
\text { cost of cultivation of cut roses was worked to Rs. } 5.97 \text { lakh and it was decreased across the } \\
\text { size group of polyhouses. The major items of cost involved were hired human labour, } \\
\text { planting material, fertilizers, plant protection chemicals and bed preparation. The average } \\
\text { profit realized was Rs. } 10,25417 \text { with B:C ratio } 1.72 \text {. The average cost of marketing was } \\
\text { estimated to Rs. } 18.60 / \text { bundle. The winter season produce had reaped the maximum prices, } \\
\text { whereas exported produce fetched more prices. In export, Channel-III (Cut roses producer } \\
\text { - Importer- Wholesaler- Retailer- Consumer) proved to be more efficient. The farmer } \\
\text { should adopt the production technology in such a way that maximum produce should be } \\
\text { available for marketing during } 25^{\text {th }} \text { January to } 10^{\text {th }} \text { February in order to reap the benefit of } \\
\text { maximum prices. }\end{array}$} \\
\hline & \\
\hline & \\
\hline Article Info & \\
\hline $\begin{array}{l}\text { Accepte } \\
04 \text { Janu } \\
\text { Availab } \\
10 \text { Febr }\end{array}$ & \\
\hline & \\
\hline
\end{tabular}

\section{Introduction}

Greenhouses in India are being used to grow vegetables and flowers all the year round. In Maharashtra, high-tech floriculture is increasing rapidly particularly in Western Maharashtra. The most conspicuous development around Pune city is the increasing entries of major players using capital-intensive techniques and bringing techno-revolution in the floriculture trade. The polyhouse technology now a day has become very popular in and around Pune city. More than 60 per cent polyhouses in the State are concentrated around Pune city. The
Maharashtra Floriculture Development Board (MFDB) is operating with its head quarter at Pune. Economic analysis of such capital intensive technique is useful for taking decisions regarding its viability as an agribusiness. Therefore, an attempt has been made in this paper to analyze the situation of production and marketing of cut roses grown under polyhouses.

\section{Materials and Methods}

As per recent statistics available with the Directorate of Horticulture, Govt. of Maharashtra, Pune, the total area under the 
polyhouse cultivation in the state is 190 ha. Of this area, 120 ha $(63.16 \%)$ is in Pune district; which is concentrated in Maval, Haveli, Shirur, Mulashi, Rajgurunagar and Ambegaon tahsils of the district. The cut flower selected for the study was roses. The relevant data pertaining to the year 2011-12 were obtained with the help of designed questionnaires by personal interview method. A sample of 30 polyhouse owners growing of cut roses will be drawn through systematic random sampling, 10 each from small (up to 0.10 ha.), medium ( 0.11 to 0.20 ha.) and large (0.21ha. and above). Tabular method of analysis was employed for analysis of data besides the use of standard concepts. The efficiency of marketing channels was estimated by using Acharya's marketing efficiency formula.

\section{Results and Discussion}

\section{General information about the polyhouses} and the produce

Two types of polyhouses were observed i.e. GH -1 naturally ventilated (67 per cent) and GH-2 partially controlled (33 per cent). The growers opined the life period of the planting material for roses as 4 - 5 years. Almost all the polyhouses were constructed between 2008-2011. The cut rose flowers had the keeping quality up to 8-9 days. The produce was grown on raised beds with drip irrigation system. Nearly 94 per cent harvesting was made with regular cuttings and 6 per cent on need basis.

\section{Establishment cost of polyhouses}

The estimated cost of erection of these polyhouses were estimated and depicted in Table 1. The average costs of construction of polyhouses were more than 23.13 Lakhs. It is more than Rs. 9.84 Lakhs, Rs. 18.85 Lakhs and Rs.40.61 Lakhs, respectively for small
(0.10 ha.) medium (0.19 ha.) and large (0.43 ha.) size groups. It can be inferred that the per unit average cost of erection of polyhouses do not very greatly with the size of polyhouses. The G.I. material was used as a framework and, therefore, the framework cost shared about $50-53$ per cent in the total cost. The other items of cost included cost towards polyfilm, shed net, systems for irrigation, spraying, fertigation, labour and other related costs. The average expected life of all the erected structures considered to be 20 years. The Government has provided 25 per cent subsidy on total cost of erection of polyhouses. Thus, average cost of erection of polyhouse was worked to Rs. 17.32 lakhs. The figures for the small, medium and large size polyhouse were Rs.7.38, 14.14 and 30.45 lakhs, respectively.

\section{Cost of cultivation}

As could be seen from Table 2 that the average cost of cultivation of cut roses were worked to Rs.5.97 lakh. It was Rs.2.70 lakh for small sized polyhouse, Rs.4.55 Lakh for medium sized polyhouse and Rs.10.66 lakh for large sized polyhouse. The Cost ' $A$ ' shared 58 to 62 per cent to the total cost of cultivation for cut roses. The major items of cost involved hired human labour, planting material, fertilizers, plant protection chemicals, bed preparation, depreciation and interest on working capital. In the Cost B, both the items i.e. rental value of owned land and interest on fixed capital together shared 25 to 36 per cent of the total cost. The family labour shared 4 to 16 per, it was more in small sized groups while less in large sized groups.

The cost of cultivation of small size group in relation to others was higher. Small size group involved intensive input use in terms of fertilizer, planting material irrigation and plant protection chemicals. The imputed cost in the case of large sized group increased due 
to more use of shed net and high quality polyfilm.

\section{Profitability of polyhouses}

The per unit price realized for all the size groups of polyhouses of cut roses was more than their respective per unit cost of production. The production cost per unit was less in large sized group while more in small size group of polyhouses. The $\mathrm{B}: \mathrm{C}$ ratio since workout to more than unity for all the size group, it could be inferred that there is economy of scale in cost of production of cut roses. The magnitude of $\mathrm{B}: \mathrm{C}$ ratio was the highest for large size group of polyhouses (2.08). The cut roses produced in large size polyhouses were more of grade- I quality, as greater than 60 per cent produce was exported and fetched higher prices as compared to other groups. The profitability could be enhanced by producing still higher quality produce (Table 3).

\section{Marketing of cut roses}

The grading is more important for high-tech produce because it directly reflects on the price. It was observed that all the growers follow the grading as per the grade specifications. For all types of produce, the corrugated rolling paper type of packaging was followed. More than 50 per cent growers sold their produces in Mumbai market, seventy per cent produce was sold through commission agents, 25 per cent through retailers and remaining 5 per cent through local sale. The intermediates charged 10 per cent commission.

\section{Marketing channels in the study area}

There are three main marketing channels existed in the area for cut roses.

Channel-I Cut roses producer - Commission Agent- Wholesaler- Retailer- Consumer
Channel-II Cut roses producer - ExporterWholesaler- Retailer- Consumer

Channel-III Cut roses producer - ImporterWholesaler- Retailer- Consumer

The disposal pattern through these channels is depicted in Table 4.

Channel-I is the preferred for the Mumbai and Pune market in the study area. Nearly 50 per cent of the produce is disposed through Channel-I.

Channel-II is preferred channel by the cut roses producers for export of their produce through agencies dealing in the export of cut roses. The exporter collects the cut roses from the producer's field and they export it in bulk quantity. Nearly 40 per cent of the produce is disposed through Channel-II. Channel-II is found to be the prominent channel for export of cut roses in the area.

Channel-III is a direct export channel where the grower sells his produce to different countries. Nearly 10 per cent of the produce is disposed through Channel-III.

\section{Cost of marketing}

As depicted in Table 5, among the various components of marketing cost, the commission of the intermediaries was the major one sharing 36- 41 per cent in the total cost of marketing for all the cut roses.

The cost of grading and packaging in a single unit shared 27 per cent and the cost of transportation shared 30- 32 per cent.

On an average, the marketing cost for bundle cut roses (containing 40 flowers) in the size class of polyhouses ranged in between Rs.18.60. The cost of marketing decrease across the size class of polyhouse 


\section{Efficiency of marketing channel}

Efficiency of the existing marketing channels was studied in order to analyze the most effective channel for marketing of cut roses in the study area.

Table 6 shows the efficiency of the market channels. The marketing efficiency of Channel-I was found to be 0.27 , while that of Channel-II was 0.36 and Channel-III was 0.38. The Channel-III was most efficient as compared to other two channels. Channel-I was mainly used for disposal of produce to Pune and Mumbai market; while Channel-II and Channel-III were used for export of produce. In export, Channel-III proved to be more efficient, but the producers commonly using Channel-II due to simplicity.

\section{Price variation in cut roses}

The average price received for cut roses was the lowest in monsoon season. The winter season had influenced the higher prices for the produce. The producer realizes maximum prices when cut roses was ready for marketing during the period of $25^{\text {th }}$ January to $10^{\text {th }}$ February to catch the demand for valentine day. The export market paid the higher prices for the produce followed by Mumbai market and Pune market. As a logic, the Grade-I produce had positive influence on the price received (Table 7 ).

Table.1 Average cost of polyhouse erection (Rs.)

\begin{tabular}{|c|c|c|c|c|c|}
\hline \multirow{2}{*}{$\begin{array}{l}\text { Sr. } \\
\text { No }\end{array}$} & \multirow[b]{2}{*}{ Particulars } & \multicolumn{3}{|c|}{ Size Group of polyhouse } & \multirow{2}{*}{$\begin{array}{l}\text { Overall } \\
(\mathrm{N}=30)\end{array}$} \\
\hline & & $\begin{array}{l}\text { Small } \\
(\mathrm{N}=10)\end{array}$ & $\begin{array}{l}\text { Medium } \\
(\mathbf{N}=10)\end{array}$ & $\begin{array}{l}\text { Large } \\
(\mathrm{N}=10)\end{array}$ & \\
\hline & Average area (ha.) & 0.10 & 0.19 & 0.43 & 0.24 \\
\hline \multirow[t]{2}{*}{1} & Framework & 512350 & 1013100 & 2027100 & 1184183 \\
\hline & $\%$ & 52.05 & 53.73 & 49.91 & 51.25 \\
\hline \multirow[t]{2}{*}{2} & Polyfilm & 147820 & 317300 & 780050 & 415056.7 \\
\hline & $\%$ & 15.02 & 16.83 & 19.21 & 17.96 \\
\hline \multirow[t]{2}{*}{3} & Shed net & 34360 & 96110 & 228570 & 119680 \\
\hline & $\%$ & 3.49 & 5.10 & 5.63 & 5.18 \\
\hline \multirow[t]{2}{*}{4} & Facility unit & 9240 & 22050 & 72180 & 34490 \\
\hline & $\%$ & 0.94 & 1.17 & 1.78 & 1.49 \\
\hline \multirow[t]{2}{*}{5} & Labour cost & 118380 & 216414 & 462900 & 265898 \\
\hline & $\%$ & 12.03 & 11.48 & 11.40 & 11.51 \\
\hline \multirow[t]{6}{*}{6} & Other cost & 162190 & 220724 & 490505 & 291139.7 \\
\hline & $\%$ & 16.48 & 11.71 & 12.08 & 12.60 \\
\hline & Total cost & 984340 & 1885698 & 4061305 & 2310448 \\
\hline & & 100 & 100 & 100 & 100 \\
\hline & Subsidy 25\% & 246085 & 471424.5 & 1015326.25 & 577611.9 \\
\hline & Net cost & 738255 & 1414274 & 3045979 & 1732836 \\
\hline
\end{tabular}


Table.2 Share of individual cost item in the total cost of cultivation of roses (\%)

\begin{tabular}{|l|l|l|l|l|l|}
\hline \multirow{2}{*}{$\begin{array}{l}\text { Sr. } \\
\text { No. }\end{array}$} & Particulars & Size Group of polyhouse & \multirow{2}{*}{ Overall } \\
& & Small & Medium & Large & \\
\hline 1 & Hired H. L. & 8.49 & 9.83 & 9.43 & 9.39 \\
\hline 2 & Machinery & 1.19 & 0.94 & 1.07 & 1.06 \\
\hline 3 & Bed (APP) & 4.05 & 4.45 & 3.90 & 4.06 \\
\hline 4 & Fumigation & 0.35 & 0.31 & 0.36 & 0.35 \\
\hline 5 & Plant Material(App) & 3.33 & 3.67 & 3.81 & 3.70 \\
\hline 6 & Fertilizer & 17.94 & 20.29 & 19.73 & 19.60 \\
\hline 7 & Irrigation & 2.04 & 2.07 & 1.83 & 1.92 \\
\hline 8 & Pl. Protection & 9.98 & 9.18 & 8.66 & 8.99 \\
\hline 9 & Land revenue & 0.15 & 0.17 & 0.11 & 0.13 \\
\hline 10 & Depreciation & 6.86 & 7.72 & 7.02 & 7.17 \\
\hline 11 & Interest on WC & 3.26 & 3.52 & 3.36 & 3.38 \\
\hline 12 & Cost A & 57.64 & 62.13 & 59.28 & 59.76 \\
\hline 13 & Rental value & 22.15 & 24.34 & 33.08 & 29.21 \\
\hline 14 & Interest onFC & 3.66 & 4.14 & 3.40 & 3.63 \\
\hline & Cost B & 83.45 & 90.61 & 95.76 & 92.59 \\
\hline & Family labour & 16.55 & 9.39 & 4.24 & 7.41 \\
\hline & Cost C & 100.00 & 100.00 & 100.00 & 100.00 \\
\hline & Cost C & 270636 & 455963 & 1066255 & 597618 \\
\hline & & & & \\
\hline
\end{tabular}

Table.3 Profitability of cut roses in polyhouse cultivation (Rs)

\begin{tabular}{|c|l|l|l|l|l|}
\hline \multirow{2}{*}{ S.No. } & \multicolumn{4}{|c|}{ Particulars } & \multicolumn{4}{|c|}{ Size Group of polyhouse } \\
\cline { 5 - 6 } & & Small & Medium & Large & Overall \\
\hline 1 & Output (No) & 157561 & 277971 & 647655 & 361062 \\
\hline 2 & Cost of cultivation & 270636 & 455963 & 1066255 & 597618 \\
\hline 3 & Cost of marketing & 80820 & 131241 & 290638 & 167566 \\
\hline 4 & Cost of production & 351456 & 587204 & 1356893 & 765184 \\
\hline 5 & Production cost /unit & 2.23 & 2.11 & 2.10 & 2.00 \\
\hline 6 & Gross returns & 392327 & 725504 & 2214980 & 1025417 \\
\hline 7 & Net returns & 40871 & 138300 & 858087 & 345753 \\
\hline 8 & Average Price/unit & 2.49 & 2.61 & 3.42 & 3.00 \\
\hline 9 & Profitability/ unit & 0.26 & 0.50 & 1.32 & 1.00 \\
\hline 10 & B.C. ratio & 1.45 & 1.59 & 2.08 & 1.72 \\
\hline & & & & & \\
\hline
\end{tabular}


Table.4 Disposal of cut roses through different channels

\begin{tabular}{|l|c|c|}
\hline \multirow{2}{*}{ Channel } & \multicolumn{2}{|c|}{ Quantity disposed } \\
\cline { 2 - 3 } & Qty (No.) & $\mathbf{\%}$ \\
\hline Channel -I & 546468 & $\mathbf{5 0 . 4 5}$ \\
\hline Channel -II & 439375 & $\mathbf{3 9 . 6 4}$ \\
\hline Channel -III & 107344 & $\mathbf{9 . 9 1}$ \\
\hline Total & $\mathbf{1 0 8 3 1 8 7}$ & $\mathbf{1 0 0}$ \\
\hline
\end{tabular}

Table.5 Average cost of marketing. (Rs./ bundle of flower)

\begin{tabular}{|c|l|c|c|c|c|}
\hline \multirow{2}{*}{ Sr.No. } & Particulars & \multicolumn{3}{|c|}{ Size Group of polyhouse } & \multirow{2}{*}{ Overall } \\
\cline { 3 - 5 } & & Small & Medium & Large & \\
\hline 1 & $\begin{array}{l}\text { Grading and } \\
\text { packaging }\end{array}$ & 5.60 & 5.10 & 4.90 & 5.00 \\
\hline 2 & Transportation & 6.50 & 6.20 & 5.30 & 5.70 \\
\hline 3 & Commission & $(31.74)$ & $(32.60)$ & $(29.42)$ & $(30.60)$ \\
\hline 4 & Other expenditure & 7.60 & 6.80 & 7.40 & 7.30 \\
& & $(37.03)$ & $(36.26)$ & $(40.95)$ & $(39.10)$ \\
\hline 5 & Total & $(3.86)$ & $(3.98)$ & $(2.60)$ & $(3.20)$ \\
\hline & & 20.50 & 18.90 & 18.00 & 18.60 \\
\hline
\end{tabular}

Table.6 Efficiency of marketing channels for cut roses (Per flower)

\begin{tabular}{|c|l|c|c|c|}
\hline Sr.No. & Particulars & Channel-I & Channel-II & Channel-III \\
\hline $\mathbf{1}$ & Price received by grower & 2.47 & 5.85 & $\mathbf{6 . 2 5}$ \\
\hline $\mathbf{2}$ & Marketing cost & 1.52 & 2.85 & $\mathbf{2 . 8 5}$ \\
\hline $\mathbf{3}$ & Price paid by consumer & 4.35 & 11.25 & $\mathbf{1 2 . 2 5}$ \\
\hline $\mathbf{4}$ & Net market margin & 1.88 & 5.40 & $\mathbf{6 . 0 0}$ \\
\hline $\mathbf{5}$ & Marketing efficiency & $\mathbf{0 . 2 7}$ & $\mathbf{0 . 3 6}$ & $\mathbf{0 . 3 8}$ \\
\hline
\end{tabular}


Table.7 Price Variations in roses (Rs./ No.)

\begin{tabular}{|c|c|c|c|c|c|c|c|c|c|}
\hline \multirow{3}{*}{$\begin{array}{l}\text { Sr. } \\
\text { No. }\end{array}$} & \multirow[t]{3}{*}{ Particulars } & \multicolumn{6}{|c|}{ Size Group of polyhouse } & \multirow{2}{*}{\multicolumn{2}{|c|}{ Overall }} \\
\hline & & \multicolumn{2}{|c|}{ Small } & \multicolumn{2}{|c|}{ Medium } & \multicolumn{2}{|c|}{ Large } & & \\
\hline & & Quantity & Price & Quantity & Price & Quantity & Price & Quantity & Price \\
\hline \multirow[t]{8}{*}{1} & Season & & & & & & & & \\
\hline & i)Winter & 63200 & 3.15 & 125645 & 3.36 & 263335 & 3.85 & 150727 & 3.30 \\
\hline & $\%$ & 40.111 & & 45.20 & & 40.66 & & 41.75 & \\
\hline & ii)Summer & 34650 & 2.95 & 56780 & 3.14 & 175580 & 3.22 & 89003 & 3.00 \\
\hline & $\%$ & 21.99 & & 20.43 & & 27.11 & & 24.65 & \\
\hline & iii)Monsoon & 59711 & 2.61 & 95545 & 2.81 & 208740 & 2.82 & 121332 & 2.73 \\
\hline & $\%$ & 37.90 & & 34.37 & & 32.23 & & 33.60 & \\
\hline & Total & 157561 & 2.9 & 277971 & 3.13 & 647655 & 3.35 & 361062 & 3.02 \\
\hline \multirow[t]{8}{*}{2} & Market & & & & & & & & \\
\hline & i)Mumbai & 55365 & 3.25 & 148136 & 3.4 & 121415 & 3.2 & 108305 & 3.30 \\
\hline & $\%$ & 35.14 & & 53.29 & & 18.75 & & 29.99 & \\
\hline & ii) Pune & 76346 & 2.77 & 78830 & 2.88 & 104700 & 2.92 & 86625.3 & 2.86 \\
\hline & $\%$ & 48.45 & & 28.36 & & 16.17 & & 23.99 & \\
\hline & iii) Export & 25850 & 4.12 & 51005 & 4.25 & 421540 & 4.85 & 166132 & 4.75 \\
\hline & $\%$ & 16.41 & & 18.35 & & 65.09 & & 46.01 & \\
\hline & Total & 157561 & 3.16 & 277971 & 3.41 & 647655 & 4.23 & 361062 & 3.86 \\
\hline \multirow[t]{8}{*}{3} & Grade & & & & & & & & \\
\hline & i) G-1 & 34663 & 3.25 & 76720 & 3.85 & 421650 & 4.45 & 177678 & 4.29 \\
\hline & $\%$ & 23.02 & & 27.60 & & 65.10 & & 49.21 & \\
\hline & ii) G-II & 60150 & 3.07 & 103405 & 3.45 & 204050 & 3.65 & 122535 & 3.50 \\
\hline & $\%$ & 39.95 & & 37.20 & & 31.51 & & 33.94 & \\
\hline & iii) G-III & 62748 & 2.15 & 97846 & 2.35 & 21955 & 2.32 & 60850 & 2.28 \\
\hline & $\%$ & 41.68 & & 35.20 & & 03.39 & & 16.85 & \\
\hline & Average & -- & 2.76 & & 3.17 & & 4.12 & 361062 & 3.36 \\
\hline
\end{tabular}

It is concluded that, the average size of polyhouse was 0.24 ha. The average cost of erection of polyhouse was 23.13 Lakhs. It is Rs. 9.84 Lakhs, Rs. 18.85 Lakhs and Rs. 40.61 Lakhs, respectively for small (0.10 ha.) medium (0.19 ha.) and large (0.43 ha.) size groups of polyhouses. The average cost of cultivation of cut roses was Rs. 5.97 lakhs and it decreased across the size group of polyhouse. The major items of cost were hired human labour, planting material, fertilizers, plant protection chemicals, rental value and interest on fixed capital due to heavy investment. The average cost of marketing was estimated to Rs. 18.60/bundle. Commission of the intermediaries was the major component of marketing cost. All the size group of polyhouses was in profit. The season, market place and grade influenced the market price of cut roses. The winter season had influenced the higher prices for the produce, exported produce fetched more price. In export, Channel-III proved to be more efficient.

\section{Suggestions}

Since the growers are commercial, they should produce more quantities of Grade-1 produce and export more quantity and sale in winter season in order to catch the higher price benefit. 
Farmer should adopt the production technology in such a way that maximum produce should be available for marketing during $25^{\text {th }}$ January to $10^{\text {th }}$ February in order to reap the benefit of maximum prices.

\section{References}

Anonymous, 1995, Cost economics of greenhouse cultivation of rose for one season. NCPA Format 43-48.

Gill, A. P. S., 1984, Modren trends in production of important cut flowers crops. Indian Horticulture., 29(2): 37

Nagalakshmi S, Nandakumar N, Palanisamy D and Sreenarayanan VV 2001. Naturally ventilated polyhouse for vegetable cultivation. South Indian Horticulture 49: 345-346.
Rajur BC, Patil BL and Basavaraj H 2008. Economics of chilli production in Karnataka. Karnataka Journal of Agricultural Sciences 21(2): 237-240.

Sindhu, G. S and Rameshkumar, 2004, Performance of rose cut flower varieties under unheated polyhouse condition. Proceeding of National Symposium on Recent Trends and Future Strategies in Ornamental Horticulture, Univ. Agric. Sci., Dharwad, Karnataka (India).

Sreedhara DS, Kerutagi MG, Basavaraja H, Kunnal LB and Dodamani MT 2013. Economics of capsicum production under protected conditions in northern Karnataka. Karnataka Journal of Agricultural Sciences 26(2): 217-219.

\section{How to cite this article:}

Waghmare, M.N. and Shendage, P.N. 2019. Economic Analysis of Production of Cut Roses under Polyhouses in Western Maharashtra. Int.J.Curr.Microbiol.App.Sci. 8(02): 234-241. doi: https://doi.org/10.20546/ijcmas.2019.802.029 